\title{
Circulating oestrogen concentrations during pregnancy in the African elephant (Loxodonta africana)
}

\author{
J. K. Hodges, Cilla Henderson and A. S. McNeilly* \\ Department of Reproduction, Institute of Zoology, Regent's Park, London NWI 4RY, and \\ * M.R.C. Reproductive Biology Unit, Centre for Reproductive Biology, 37 Chalmers Street, \\ Edinburgh EH3 9EW, U.K.
}

\begin{abstract}
Summary. Oestrone, oestradiol- $17 \beta$ and oestriol were measured in plasma samples from non-pregnant and pregnant African elephants shot in the wild. Enzymic hydrolysis of plasma showed that approximately 90 and $96 \%$ of the total (i.e. conjugated plus unconjugated) concentrations of oestrone and oestradiol-17 $\beta$, respectively were represented by conjugated hormones. Unconjugated oestrogens remained low $(<50$ $\mathrm{pg} / \mathrm{ml}$ ) in all samples, with no distinction between non-pregnant and pregnant animals. Levels of total oestrone during pregnancy varied between 160 and $594 \mathrm{pg} / \mathrm{ml}$ but were not significantly different from non-pregnant values. Total oestradiol- $17 \beta$ concentrations were significantly elevated during pregnancy $(P<0.01)$ and, despite considerable individual variation (193-1428 pg/ml), were consistently higher than non-pregnant values after 6 months of gestation. The elevated levels of oestradiol-17 $\beta$ resulted in a reversal of the total oestradiol-17 $\beta$ : oestrone concentration ratio at about 6 months of pregnancy. Concentrations of total oestriol did not exceed $103 \mathrm{pg} / \mathrm{ml}$. An indirect method of measurement indicated that oestradiol- $17 \beta$ sulphate was probably the most abundant circulating oestrogen during pregnancy in the African elephant.
\end{abstract}

\section{Introduction}

There are very few data on the hormonal characteristics of pregnancy in the Asian or African elephant. Those which do exist have indicated unusually low levels of steroids in luteal tissue (Smith, Hanks \& Short, 1969; Hanks \& Short, 1972) and in the blood (Plotka, Seal, Schobert \& Schmoller, 1975) compared with other mammals, and have been unable to provide any clear endocrine distinction between the pregnant and non-pregnant condition. However, McNeilly, Martin, Hodges \& Smuts (1983) have now reported a modest, but significant, elevation in blood progesterone and a marked increase in prolactin levels during pregnancy in the African elephant. In this paper the circulating oestrogen concentrations during pregnancy are described.

\section{Materials and Methods}

\section{Sample collection}

The plasma samples used in this study were from 22 pregnant and 5 non-pregnant African elephants killed by shooting in the Kruger National Park, South Africa, in August 1977 and in February and April 1978. Details of blood collection and the preparation, storage and transport of plasma are described by McNeilly et al. (1983). Non-pregnant elephants were judged to be sexually 
mature by age determination (range 15-32 years; Laws, 1966) and from evidence of previous ovulation (i.e. presence of corpora lutea or corpora albicantia). Large follicles were present in the ovaries from 3 of the 5 non-pregnant animals. Stage of pregnancy was estimated from measurement of fetal weight and crown-rump length according to the method of Perry (1953) and Laws \& Parker (1968). The ages of pregnant animals were 9-36 years.

\section{Hormone assays}

Unconjugated oestrone, oestradiol-17 $\beta$ and oestriol in plasma $(1.0 \mathrm{ml})$ were measured by radioimmunoassay procedures previously described (Hodges, Brand, Henderson \& Kelly, 1983). The concentration of total oestrogen (i.e. conjugated plus unconjugated) was measured by incorporating an enzymic hydrolysis step before assay (Hodges et al., 1983). Plasma $(0.3 \mathrm{ml})$ was hydrolysed by adding 0.005 ml $\beta$-glucuronidase arylsulphatase (Sigma Chemical Co., Poole, England) in 0.6 ml phosphate-saline buffer (PBS, $\mathrm{pH} 5.0$ ) or $0.015 \mathrm{ml} \beta$-glucuronidase (Pasteur Institute, Paris, France) in $0.6 \mathrm{ml} \mathrm{PBS} \mathrm{(pH} \mathrm{7.0)} \mathrm{and} \mathrm{incubation} \mathrm{for} 20 \mathrm{~h}$ at $37^{\circ} \mathrm{C}$. The volumes of each enzyme preparation were chosen to contain equivalent glucuronidase activities (600 Fishman units) under optimum conditions; the Sigma preparation contained an additional 16.4 units of sulphatase activity per $0.005 \mathrm{ml}$ ( 1 unit hydrolyses $1 \mu \mathrm{M}$ nitrocatechol sulphate $/ \mathrm{h}$ at $\mathrm{pH} 5.0$ and $37^{\circ} \mathrm{C}$ ). No appreciable sulphatase activity was found in the glucuronidase preparation. All total hormone concentrations reported here, with the exception of those indicated in Table 1, are after hydrolysis with glucuronidase arylsulphatase.

Tracer amounts of $\left[{ }^{3} \mathrm{H}\right]$ oestrone and $\left[{ }^{3} \mathrm{H}\right]$ oestradiol- $17 \beta$ (sp. act. $92 \mathrm{Ci} / \mathrm{mmol}$ and $100 \mathrm{Ci} / \mathrm{mmol}$ respectively) or [ ${ }^{3} \mathrm{H}$ ]oestriol (sp. act. $114 \mathrm{Ci} / \mathrm{mmol}$; Radiochemical Centre, Amersham) were added to hydrolysed and non-hydrolysed samples before extraction with re-distilled diethyl ether. The extractants were dried under nitrogen, reconstituted in the appropriate organic solvents and subjected to celite column chromatography (Hodges, Gulick, Czekala \& Lasley, 1981). Selected fractions were evaporated to dryness, reconstituted in assay buffer and separate aliquots taken for assay (in duplicate) and recovery determination. The mean \pm s.e.m. recovery values for the oestrone, oestradiol-17 $\beta$ and oestriol assays were $67.6 \pm 1 \cdot 1 \%(n=64), 61 \cdot 8 \pm 0.6 \%(n=78)$ and $73.4 \pm 3.0 \%(n=10)$, respectively.

The origins and specificities of the antisera used here have been described (Hodges et al., 1983). The sensitivity of each assay, defined as the minimum hormone concentration detectable/ml elephant plasma was $21 \mathrm{pg}$ oestrone, $20 \mathrm{pg}$ oestradiol- $17 \beta$ and $12 \mathrm{pg}$ oestriol for unconjugated hormone and $86 \mathrm{pg}$ oestrone, $83 \mathrm{pg}$ oestradiol-17 $\beta$ and $40 \mathrm{pg}$ oestriol for total hormone (after hydrolysis). Buffer and hydrolysis enzyme blanks which were extracted and run through celite for each assay gave values less than the sensitivities of the respective assays. Interassay precision, expressed as the coefficient of variation for replicate determinations of a low and a high value plasma pool, was 6.7 and $11.2 \%(n=5)$ for oestrone and 10.7 and $11.6 \%(n=5)$ for oestradiol. Oestriol measurements were performed in a single assay. Intra-assay precision was $<8 \%$ for each hormone.

Validation of the measurement of oestrogens was achieved by performing celite column cochromatography and comparing the profile of immunoreactivity with that of pure tritiated steroid across the appropriate elution fractions at $0.5 \mathrm{ml}$ intervals (Hodges et al., 1983). Text-figure 1(a) illustrates this procedure for oestrone and oestradiol-17 $\beta$ measured in a randomly selected plasma sample after hydrolysis.

Continuous elution reverse-phase high-pressure liquid chromatography was also performed on one sample from mid-pregnancy to determine whether immunoreactive oestrogens other than oestrone, oestradiol-17 $\beta$ and oestriol were present in significant amounts. Details of the procedure have been previously reported (Hodges et al., 1981). Oestrogen immunoreactivity in each $0.5 \mathrm{ml}$ fraction eluted from the column was measured using an oestriol trisuccinyl-directed antibody nonspecific for oestrogens (Tulchinsky \& Abraham, 1971). Tracer amounts of $\left[{ }^{3} \mathrm{H}\right]$ oestrone, 
$\left[{ }^{3} \mathrm{H}\right.$ ]oestradiol-17 $\beta$ and $\left[{ }^{3} \mathrm{H}\right]$ oestriol were added to the sample before extraction and chromatography to indicate their elution positions on the column.

The results from all measurements are reported. Unconjugated oestrogens and total oestriol were not measured in every sample due to insufficient volume of plasma.

\section{Statistical analysis}

Oestrogen concentrations in non-pregnant and pregnant animals were compared by Wilcoxons rank sum test for unpaired data. Concentration ratios were compared by Student's $t$ test.

\section{Results}

Co-chromatographic analysis of pure tritiated oestrone and oestradiol-17 $\beta$ and plasma oestrogen immunoreactivity in the fractions taken to assay is shown in Text-fig. 1(a). The similarity between the profiles of immunoreactivity and radioactivity was taken to indicate the absence of any substantial contamination from cross-reacting substances. Continuous elution reverse-phase HPLC (Text-fig. 1(b)) shows the relative levels of various component oestrogens in a plasma sample from mid pregnancy. Oestradiol-17 $\beta$ and oestrone accounted for most of the oestrogen present although additional immunoreactivity was found in fractions $19-20$ and $52-56$.

Circulating concentrations of unconjugated and total oestrone in pregnant and non-pregnant animals are shown in Text-fig. 2(a). Levels of unconjugated oestrone were extremely low in all samples and there was no obvious distinction between values for non-pregnant $(<21-35 \mathrm{pg} / \mathrm{ml})$ and pregnant $(<21-53 \mathrm{pg} / \mathrm{ml})$ animals. Concentrations were undetectable $(<21 \mathrm{pg} / \mathrm{ml})$ in 1 of 3 samples from non-pregnant and 5 of 15 samples from pregnant elephants. Concentrations of total

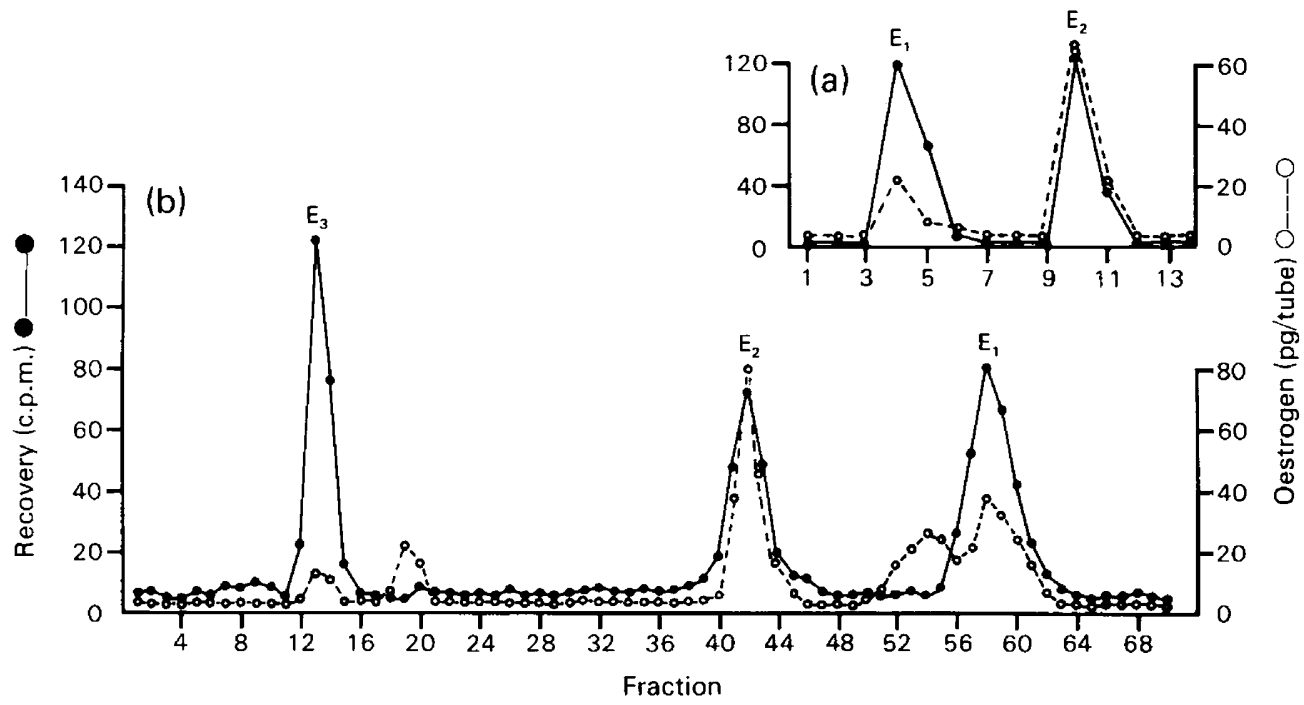

Text-fig. 1. Chromatography of plasma oestrogens of the African elephant. (a) Celite column co-chromatography of oestrone $\left(E_{1}\right)$ and oestradiol- $17 \beta\left(E_{2}\right)$ in hydrolysed plasma. Oestrogen immunoreactivity measured by specific oestrone and oestradiol-17 $7 \beta$ antibodies is compared with recovery of pure tritiated hormone in $0.5 \mathrm{ml}$ fractions across the entire eluate taken for assay ( $3.5 \mathrm{ml}$ for each hormone). (b) High-pressure liquid chromatography separation of etherextracted, hydrolysed plasma from an elephant 12 months pregnant. The profile of oestrogen immunoreactivity measured by non-specific oestrogen antibody is compared with the recovery of $\left[{ }^{3} \mathrm{H}\right]$ oestrone $\left(\mathrm{E}_{1}\right),\left[{ }^{3} \mathrm{H}\right]$ oestradiol $\left(\mathrm{E}_{2}\right)$ and $\left[{ }^{3} \mathrm{H}\right]$ oestriol $\left(\mathrm{E}_{3}\right)$. 


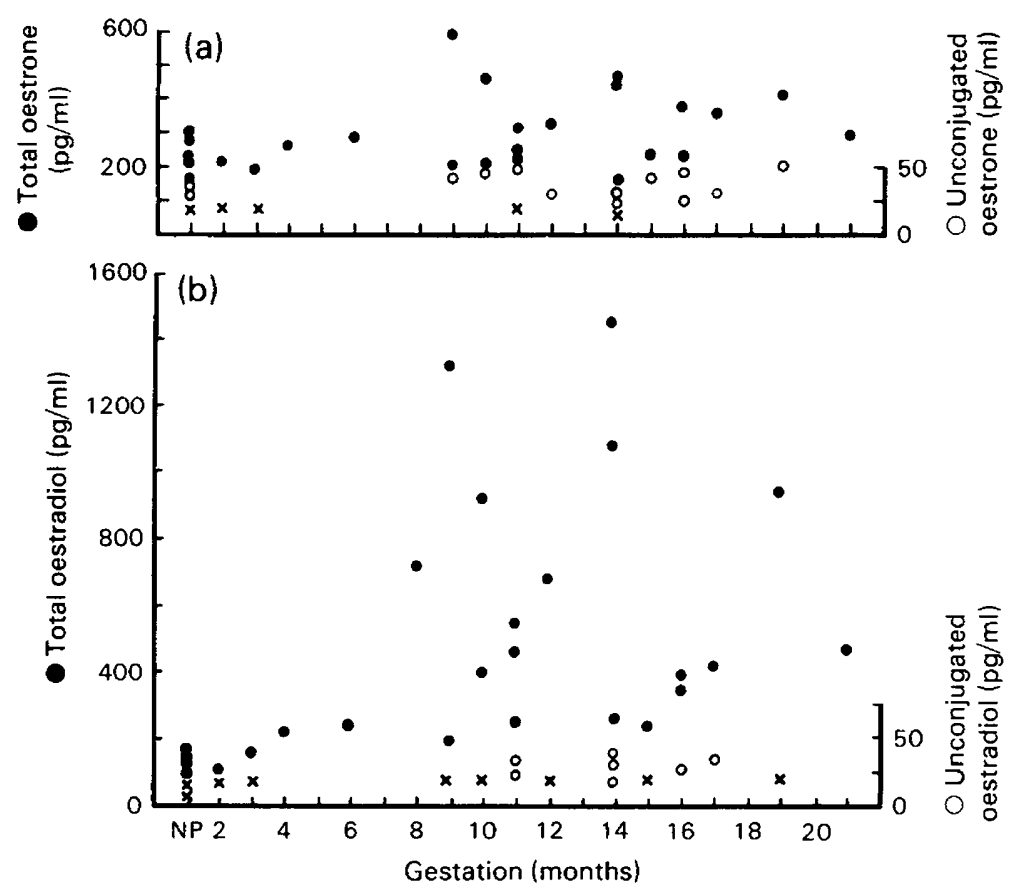

Text-fig. 2. Plasma concentrations of unconjugated and total oestrone (a) and oestradiol-17 $\beta$ (b) in non-pregnant (NP) and pregnant elephants. Values below the limit of the assay are indicated by $x$.

oestrone were much higher, $160-290 \mathrm{pg} / \mathrm{ml}$ for non-pregnant animals and 161-594 pg/ml throughout gestation. The highest values were measured after 9 months of gestation although about $50 \%$ of the values during this period remained in the non-pregnant range. There was no significant difference between total oestrone concentrations in non-pregnant and pregnant animals $(P>0.05)$. In samples in which unconjugated oestrone could be detected, $88.9 \pm 1.9 \%$ of the value for total oestrone could be accounted for by conjugated hormone (mean \pm s.e.m., $n=11$ ).

Concentrations of unconjugated oestradiol- $17 \beta$ also remained low during pregnancy $(<20-41$ $\mathrm{pg} / \mathrm{ml}$, pregnant ; $<20-32 \mathrm{pg} / \mathrm{ml}$, non-pregnant) as shown in Text-fig. 2(b). Values in 2 of 3 nonpregnant and 7 of 14 pregnant animals were undetectable $(<20 \mathrm{pg} / \mathrm{ml})$. However, the concentrations of total oestradiol- $17 \beta$ during pregnancy (mean \pm s.e.m., $498.9 \pm 72.3 \mathrm{pg} / \mathrm{ml}$, $n=22$; range $116-1428 \mathrm{pg} / \mathrm{ml}$ ) were significantly higher than those in samples from non-pregnant animals (mean \pm s.e.m., $157 \pm 6 \mathrm{pg} / \mathrm{ml}, n=5$; range $120-186 \mathrm{pg} / \mathrm{ml})(P<0.01)$. Furthermore, despite considerable individual variation, concentrations of total oestradiol-17 $\beta$ after 6 months gestation were consistently higher than values in non-pregnant animals. In 7 samples in which the levels of unconjugated oestradiol- $17 \beta$ were detectable, $95.8 \pm 1.0 \%$ of the value for total oestradiol$17 \beta$ was accounted for by conjugated hormone.

Levels of unconjugated oestriol were undetectable $(<12 \mathrm{pg} / \mathrm{ml})$ in all samples measured. The concentration of total oestriol in 1 non-pregnant elephant was $89 \mathrm{pg} / \mathrm{ml}$, whereas levels in 4 pregnant animals (7-16 months) varied between 52 and $103 \mathrm{pg} / \mathrm{ml}$.

Comparison between concentrations of unconjugated oestrone and oestradiol- $17 \beta$ is difficult because of the large proportion of undetectable values. However, in those samples with detectable levels of both unconjugated hormones the mean \pm s.e.m. concentration ratio of oestradiol$17 \beta$ : oestrone was $0 \cdot 86 \pm 0 \cdot 1(n=7)$. Concentrations of total oestradiol-17 $\beta$ were lower than those of total oestrone in all samples from non-pregnant animals $(n=5)$ and pregnant animals up to 6 
Table 1. Circulating concentrations of oestrone and oestradiol-17 $\beta$, measured after hydrolysis with two different enzyme preparations in non-pregnant and pregnant elephants

\begin{tabular}{|c|c|c|c|c|}
\hline \multirow[b]{2}{*}{ Condition } & \multicolumn{2}{|c|}{ Oestrone $(\mathrm{pg} / \mathrm{ml})$} & \multicolumn{2}{|c|}{ Oestradiol-17ß (pg/ml) } \\
\hline & Glucuronidase & $\begin{array}{l}\text { Glucuronidase } \\
\text { arylsulphatase }\end{array}$ & Glucuronidase & $\begin{array}{l}\text { Glucuronidase } \\
\text { arylsulphatase }\end{array}$ \\
\hline Not pregnant & 98 & 206 & 34 & 85 \\
\hline & 95 & 170 & 47 & 106 \\
\hline Pregnant -10 months & 149 & 386 & 85 & 544 \\
\hline-14 months & 104 & 443 & 52 & 960 \\
\hline-22 months & 151 & 348 & 45 & 329 \\
\hline
\end{tabular}

months of gestation $(n=4)$. In contrast, in 17 of 18 samples from animals beyond 6 months of gestation, values for total oestradiol- $17 \beta$ exceeded those of total oestrone. Furthermore, the total oestradiol-17 $\beta$ :oestrone concentration ratio during pregnancy (mean \pm s.e.m., $1 \cdot 50 \pm 0 \cdot 16$, $n=22$ ) was significantly greater than that in non-pregnant animals (mean \pm s.e.m., $0.73 \pm 0 \cdot 1$, $n=5)(P<0.05)$.

The effect of hydrolysis using enzyme preparations with and without additional sulphatase activity on levels of oestrone and oestradiol-17 $\beta$ in selected samples is shown in Table 1 . Whilst glucuronidase alone increased the concentrations of both hormones (compare with unconjugated levels in Text-figs $2 \mathrm{a} \& \mathrm{~b}$ ), most of the increase in oestrogen immunoreactivity after hydrolysis was associated with the sulphatase enzyme. The difference between the effects of the two enzymes was greater for oestradiol than for oestrone.

\section{Discussion}

This paper provides the first detailed account of circulating levels of oestrone and oestradiol-17 $\beta$ during pregnancy in the African elephant. The pattern of low. levels of unconjugated oestrogens confirms a previous report (Plotka et al., 1975) describing oestrogen concentrations of $12-37 \mathrm{pg} / \mathrm{ml}$ (measured by non-specific oestradiol antibody) in 8 samples from Asian and African elephants in various reproductive states. In agreement with the present results there was no evidence for an increase in unconjugated oestrogen levels associated with pregnancy. The only other report of circulating oestrogens in the elephant is by Chappel \& Schmidt (1979) who measured concentrations of oestradiol- $17 \beta$ of up to $13 \mathrm{pg} / \mathrm{ml}$ during oestrus in a single Asian elephant.

Although the concentrations of unconjugated oestrone and oestradiol in the elephant remain low during pregnancy, other unconjugated oestrogens may be more abundant. Nevertheless, the levels of oestrogen reported here compare with those found throughout much of gestation in several domestic species including sheep (Challis, 1971; Liggins, Fairclough, Grieves, Forster \& Knox, 1977) and cattle (Wettemann \& Hafs, 1973; Hoffman, Wagner, Rattenberger \& Schmidt, 1977). It is not known whether there is an increase in unconjugated oestrogen concentrations during late pregnancy in the elephant comparable with that described for the sheep and cow (Challis, 1971; Hoffman et al., 1977).

The present results demonstrate that most of the circulating oestrone and oestradiol-17 $7 \beta$ in the African elephant is in conjugated form. In many other species in which elevated concentrations of conjugated oestrogens are a feature of pregnancy, oestrone sulphate is present in greatest quantities (Loriaux, Ruder \& Lipsett, 1971 ; Robertson \& King, 1974; Tsang, Hackett \& Turner, 1975; Tsang \& Hackett, 1979). Based on an indirect method of estimation, the present data suggest that the most abundant oestrogen during pregnancy in the African elephant is oestradiol-17 $\beta$ sulphate. Direct measurement of individual oestrogen conjugates is needed to confirm this. The HPLC data suggest 
that conjugates of oestrone and oestradiol- $17 \beta$ account for most of the overall oestrogen immunoreactivity in the sample at 12 months of gestation. However, the proportion of 'total' oestrogen represented by oestrone and oestradiol-17 $\beta$ at other stages of pregnancy is not necessarily the same, and it cannot be assumed that the sample is representative of the oestrogen concentrations in other elephants.

The preferential increase in conjugated oestradiol-17 7 during pregnancy results in a reversal of the total oestradiol-17 $\beta$ :oestrone concentration ratio. Although this ratio is significantly higher in pregnant than in non-pregnant animals when all samples are included, total oestrone continues to be more abundant than oestradiol-17 $\beta$ during the early stages of pregnancy, and the reversal of the concentration ratio coincides with the appearance of elevated concentrations of conjugated oestradiol-17 $\beta$ at about 6 months gestation. McNeilly et al. (1983) have shown that prolactin levels also begin to increase at about this time and have suggested that the two events are related, as indeed they appear to be in several other species during pregnancy (Cowie, Forsyth \& Hart, 1980).

The significance of the increase in total oestradiol- $17 \beta$ concentrations in relation to the control of pregnancy in the elephant is obscure, particularly in view of the considerable variation in levels between individuals. Circulating concentrations of hormones do not necessarily reflect their secretion and nothing is known of the production or metabolism of oestrogens in the elephant. Similarly, the relative contribution of the ovary and conceptus to circulating oestrogen concentrations is not known. An ovarian follicular source is unlikely as follicular development is repressed between 5 and 16 months of pregnancy (Smith \& Buss, 1975) and there is a decline in LH and FSH levels over a similar period (McNeilly et al., 1983). Histologically, the corpus luteum appears most steroidogenically active between 2 and 14 months of pregnancy (Smith \& Buss, 1975). Although there is evidence to suggest that plasma levels of progesterone increase during pregnancy in relation to an increase in the number of corpora lutea (McNeilly et al., 1983), such a relationship in terms of oestrogen concentrations has yet to be examined.

From a practical point of view, diagnosis of pregnancy in the elephant presents considerable difficulties. Until recently, the development of and appearance of milk in the mammary glands in the second half of gestation together with an absence of cyclic oestrous behaviour were the only reliable criteria for use in pregnancy diagnosis. McNeilly et al. (1983) have described the potential for pregnancy diagnosis at 7 months using the measurement of plasma prolactin. The present study suggests that measurement of conjugated oestradiol-17 $\beta$ or the concentration ratio of oestradiol$17 \beta$ : oestrone may also be informative by this stage in pregnancy, although combined analysis of prolactin and oestrogen would allow a more confident diagnosis. Urinary oestrogens are measurable during the oestrous cycle of the Asian elephant (Ramsay, Lasley \& Stabenfeldt, 1981) but their levels during pregnancy have not been reported. The identification of the appropriate oestrogen metabolite in urine would be of much greater practical value for pregnancy diagnosis of elephants both in captivity and in the wild.

We thank Dr G. L. Smuts and Dr R. D. Martin for the collection and supply of samples. The study was funded in part by a grant from the Advisory Board to the Research Councils to the Institute of Zoology.

\section{References}

Challis, J.R.G. (1971) Sharp increase in free circulating oestrogens immediately before parturition in sheep. Nature, Lond. 229, 208.

Chappel, S.C. \& Schmidt, M. (1979) Cyclic release of luteinizing hormone and the effects of luteinizing hormone-releasing hormone injection in Asiatic elephants. Am. J. vet. Res. 40, 451-453.
Cowie, A.T., Forsyth, I.A. \& Hart, I.C. (1980) Hormonal Control of Lactation. Springer-Verlag, Berlin.

Hanks, J. \& Short, R.V. (1972) The formation and function of the corpus luteum in the African elephant, Loxodonta africana. J. Reprod. Fert. 29, 7989.

Hodges, J.K., Gulick, B.A., Czekala, N.M. \& Lasley, B.L. 
(1981) Comparison of urinary oestrogen excretion in South American primates. J. Reprod. Fert. 61, 83-90.

Hodges, J.K., Brand, H.M., Henderson, C. \& Kelly, R.W. (1983) Levels of circulating and urinary oestrogens during pregnancy in the marmoset monkey, Callithrix jacchus. J. Reprod. Fert. 67, 73-82.

Hoffman, B., Wagner, W.C., Rattenberger, E. \& Schmidt, 3. (1977) Endocrine relationships during late gestation and parturition in the cow. In The Fetus and Birth (Ciba Fdn Symp. No. 47), pp. 107-125. Elsevier/ Excerpta Medica/North-Holland, Amsterdam.

Laws, R.M. (1966) Age criteria for the African elephant, Loxodonta africana. E. Afr. Wildl. J. 4, 1-37.

Laws, R.M. \& Parker, I.S.C. (1968) Recent studies on elephant populations in East Africa. Symp. zool. Soc. Lond. 21, 319-359.

Liggins, G.C., Fairclough, R.J., Grieves, S.A., Forster, C.S. \& Knox, B.S. (1977) Parturition in the sheep. In The Fetus and Birth (Ciba Fdn Symp. No. 47), pp. 530. Elsevier Excerpta Medica North-Holland, Amsterdam.

Loriaux, D.L., Ruder, H.J. \& Lipsett, M.B. (1971) The measurement of oestrone sulphate in plasma. Steroids 18. 463-472.

McNeilly, A.S., Martin, R.D., Hodges, J.K. \& Smuts, G.L. (1983) Concentrations of gonadotrophins, prolactin and gonadal steroids in males and in nonpregnant and pregnant female African elephants (Loxodonta africana). J. Reprod. Fert. 67, 113-120.

Perry, J.S. (1953) The reproduction of the African elephant Loxodonta africana. Phil. Trans. R. Soc. B 237, 93-149.
Plotka, E.D., Seal, U.S., Schobert, E.E. \& Schmoller, G.C. (1975) Serum progesterone and estrogens in elephants. Endocrinology 97, 485-487.

Ramsay, E.C., Lasley, B.L. \& Stabenfeldt, G.H. (1981) Monitoring the estrous cycle of the Asian elephant (Elephas maximus), using urinary estrogens. Am. J. vet. Res. 42, 256-260.

Robertson, H.A. King, G.J. (1974) Plasma concentrations of progesterone, oestrone, oestradiol-17 $\beta$ and oestrone sulphate in the pig at implantation, during pregnancy and at parturition. J. Reprod. Fert. 40, $133-141$.

Smith, J.G., Hanks, J. \& Short, R.V. (1969) Biochemical observations on the corpora lutea of the African elephant (Loxodonta africana). J. Reprod. Fert. 20, 111117.

Smith, N.S. \& Buss, I.O. (1975) Formation, function and persistence of the corpora lutea of the African elephant (Loxodonta africana). J. Mammal. 56, 30-43.

Tsang, C.P.W. \& Hackett, A.J. (1979) Metabolism of estrone sulphate in the pregnant sheep. Theriogeno$\log y$ 11, 429-440.

Tsang, C.P.W., Hackett, A.J. \& Turner, E.M., Jr (1975) Plasma levels of estrone sulphate, estrone and estradiol-17ß in the cow around parturition. Can.J. Anim. Sci. 55, 509-512.

Tulchinsky, D. \& Abraham, G.E. (1971) Radioimmunoassay of plasma estriol. J. clin. Endocr. Metab. 32, 775-782.

Wettemann, R.P. \& Hafs, H.D. (1973) LH, prolactin, estradiol and progesterone in bovine blood serum during early pregnancy. J. Anim. Sci. 36, 51-56.

Received 18 May 1982 